\title{
Performance, Combustion and Emission Characteristics of a Diesel Engine Fuelled with the Annona Squamosa Seed Cake Pyrolysis Oil
}

\author{
P. Sathish Kumar ${ }^{1}$, S. Periyasamy ${ }^{2}$ \\ PG scholar, Department of Mechanical Engineering, Government College of Technology, Coimbatore, India ${ }^{1}$ \\ Assistant Professor, Department of Mechanical Engineering, Government College of Technology, Coimbatore, India ${ }^{2}$
}

\begin{abstract}
This paper presents the performance, combustion and emission characteristics of a bio-oil obtained from Annona squamosa oil seed which is available across all over India. Pyrolysis was carried out between $450^{\circ} \mathrm{C}$ and $550^{\circ} \mathrm{C}$ under semi-batch type reactor for the production of Annona squamosa seed cake oil. The yield of the Annona squamosa seed cake oil was found to be about $40 \%$ at an optimum temperature of $500^{\circ} \mathrm{C}$. The pyrolysis oil was also characterized for its suitability of using it as an alternative fuel for internal combustion engines. The combustion, performance, and emission behaviour of the diesel engine operated with the different Annona squamosa seed cake oil-diesel blends were assessed and compared with those of diesel operation at different loads. The results indicated that the engine brake thermal efficiency was increased by about $27 \%$ for Annona squamosa seed cake oil-diesel blend of 20 percentage operation from no load to full load operation in comparison to diesel. The Brake specific energy consumption gets decreased by $20 \%$ for the B20 blend ratio compared to the diesel at full load condition. As the Annona squamosa seed cake oil -diesel blend ratio increases, the lower NO emission was found to be about $28 \%$ for B20, in comparison with diesel at full load condition. From the obtained results, it is suggested that the 20\% Annona squamosa seed cake biooil blend can be considered as a potential candidate to be used as a fuel in compression ignition engines.
\end{abstract}

Keywords: Annona Squamosa, Seed, Pyrolysis, Brake Thermal Efficiency (BTE), Brake Specific Energy Consumption (BSEC), NO Emission

\section{INTRODUCTION}

The demand in the energy source has been increased due to the exploitation of the fossil fuels. According to the Energy statistics 2017 given by the ministry of statistics and programme implementation the consumption of the petroleum product has been increased by $4.31 \%$ in the year 2016 compared to 2015[1].The emission of the greenhouse gases and impact in the global warming affects the environment and therefore there is a need of an alternative renewable energy sources. The bio fuels from the plant biomass are the solution to overcome the energy crisis in today's world and it also leads to the economic development of the country. Biomass is solid waste agricultural product and it can be converted into the bio fuels through a various conversion process such as gasification, liquefaction, combustion and pyrolysis. Among them pyrolysis has gained attention because of the maximum yield of biooil with the by-products of solid char and non-condensable gases. Pyrolysis is the thermal decomposition process of the biomass under the absence of oxygen. Annona squamosa is one of the finest fruits introduced in India from America.it is also found in wild form in many parts of India. It is a medium-sized tree and grow as much as two to three meters, which comes under the sour sop family. The oil content present in the seeds are about 40 to 50 percent, which is similar to aegle marmelos oil [2].

The bio-oil composed of different qualities of hydrocarbon compounds and moisture content, and also acidic in nature. Most of the bio-oils are denser than diesel fuels but have low heating values. Also, the bio-oil requires a necessary pretreatment to remove water content and neutralize before using it as an alter-native fuel in compression ignition (CI) engine. Many experiments have already been conducted to determine the performance and emission of a diesel engine run on bio-oil.Vikranth et al [3,4] used the mustard cake pyrolytic oil blends in a diesel engine and found that $30 \%$ blend gave $4.7 \%$ higher brake thermal efficiency and lower exhaust emissions compared to diesel.

The utilization of bio-oil derived from pyrolysis of waste wood was investigated by Seokhwan Lee [5].in a diesel engine for replacement of petroleum fuel. S.Murugan [6] investigated on the tyre pyrolysis oil obtained from automobile tyres as a fuel in diesel engines. The 20 percentage of tyre pyrolysis oil gives better thermal efficiency compared to other blends.Debalaxmi Pradhan [7] conducted an experiment on the utilization of biooil derived from the pyrolysis of Mahua seed and found that the $30 \%$ blend gives a better performance as a fuel in compression ignition 


\section{International Advanced Research Journal in Science, Engineering and Technology}

Vol. 6, Issue 5, May 2019

engines. Many research works have been performed on minimizing the problems associated with the use of bio-oils in the CI engines. The continuous search for potential liquid alternative fuels for diesel engines has been carried out using various biomass feed stocks.

In this investigation, the biooil obtained by the pyrolysis process was pretreated for reducing its acidity and then blended with diesel at three different percentages from 10 to $20 \%$ on a volume basis in steps of $5 \%$ in the blend, and used as fuels in a single cylinder, four stroke, water-cooled direct injection (DI) diesel engine. The blends were denoted as B10, B15and B20 where the numeric value indicates the percentage of Annona squamosa seed cake oil in the blend. The combustion, performance and emission parameters of the engine run on the three different Annona squamosa seed cake oil-diesel blends were evaluated, compared with the diesel fuel operation and presented.

\section{MATERIALS AND METHODS}

\section{A. Production of bio oil}

The production of Annona squamosa seed cake bio oil was obtained from the lab scale fixed bed pyrolysis reactor. The schematic diagram of the reactor is shown in fig 1. Pyrolysis setup consists of a semi-batch stainless steel reactor having $17.5 \mathrm{~cm}$ length with the inside and outer diameter 4.7 and $5 \mathrm{~cm}$ respectively. A lab scale fixed bed reactor with the capacity of $2 \mathrm{~kg}$ shown in fig was used to conduct the pyrolysis process of Annona squamosa seed cake. The contaminants present in the reactor were cleaned prior to the experiment. An electrical heater of $240 \mathrm{~V}$ and $9.5 \mathrm{~A}$ was employed to heat the sample in the absence of oxygen to raise the temperature of the sample. The PID controller coupled with K-type thermocouple was used to regulate the temperature of the reactor and the heating rate of $10^{\circ} \mathrm{C}$ has been adjusted with the help of dimmerstat. The gases evolved during the process was passed in the water cooled condenser which was placed at the outlet of the reactor. The gases are condensed to the liquid oil that are collected in the conical flask and some of the gases are non-condensable which are collected in the bladder and the non-condensable gases consists of some hydrocarbons and they are tested by GC analysis.

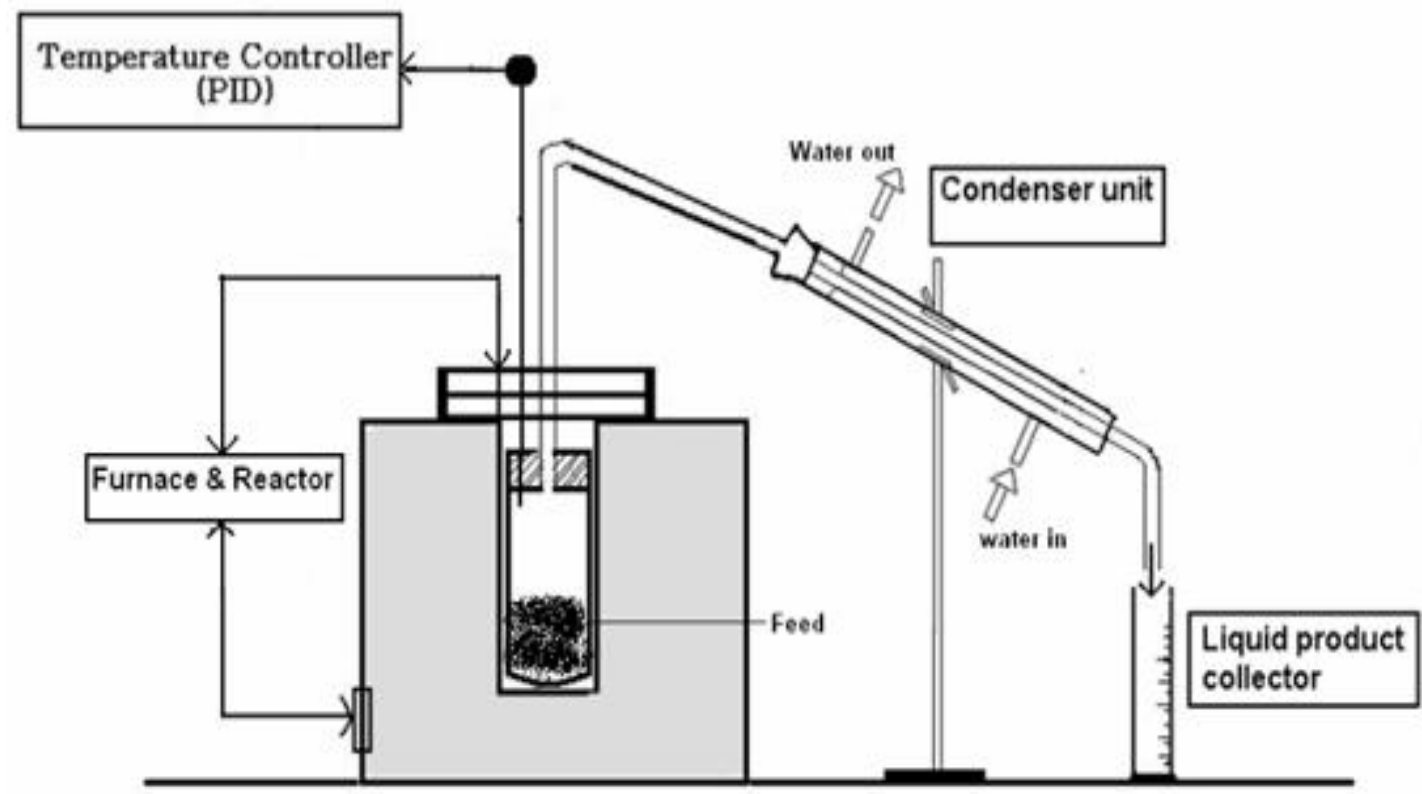

Fig 1 Fixed bed pyrolysis reactor

\section{B. Engine Experimental setup}

The experimental test rig consists of a variable compression ratio compression ignition engine, eddy current dynamometer as loading system, fuel supply system, water cooling system, lubrication system and various sensors and instruments integrated with computerized data acquisition system for online measurement of load, air and fuel flow rate, instantaneous cylinder pressure, injection pressure, position of crank angle, exhaust emissions and smoke opacity. Figure. 2 represents the schematic representation of the experimental test setup. The setup enables the evaluation of thermal performance and emission constituents of the VCR engine. The thermal performance parameters include brake power, brake mean effective pressure, brake thermal efficiency, volumetric efficiency, brake specific fuel consumption, exhaust gas temperature, heat equivalent of brake power and heat equivalent of exhaust gas. Commercially available lab view based Engine Performance Analysis software package IC Engine soft is used for on line performance evaluation. 


\section{International Advanced Research Journal in Science, Engineering and Technology}

Vol. 6, Issue 5, May 2019

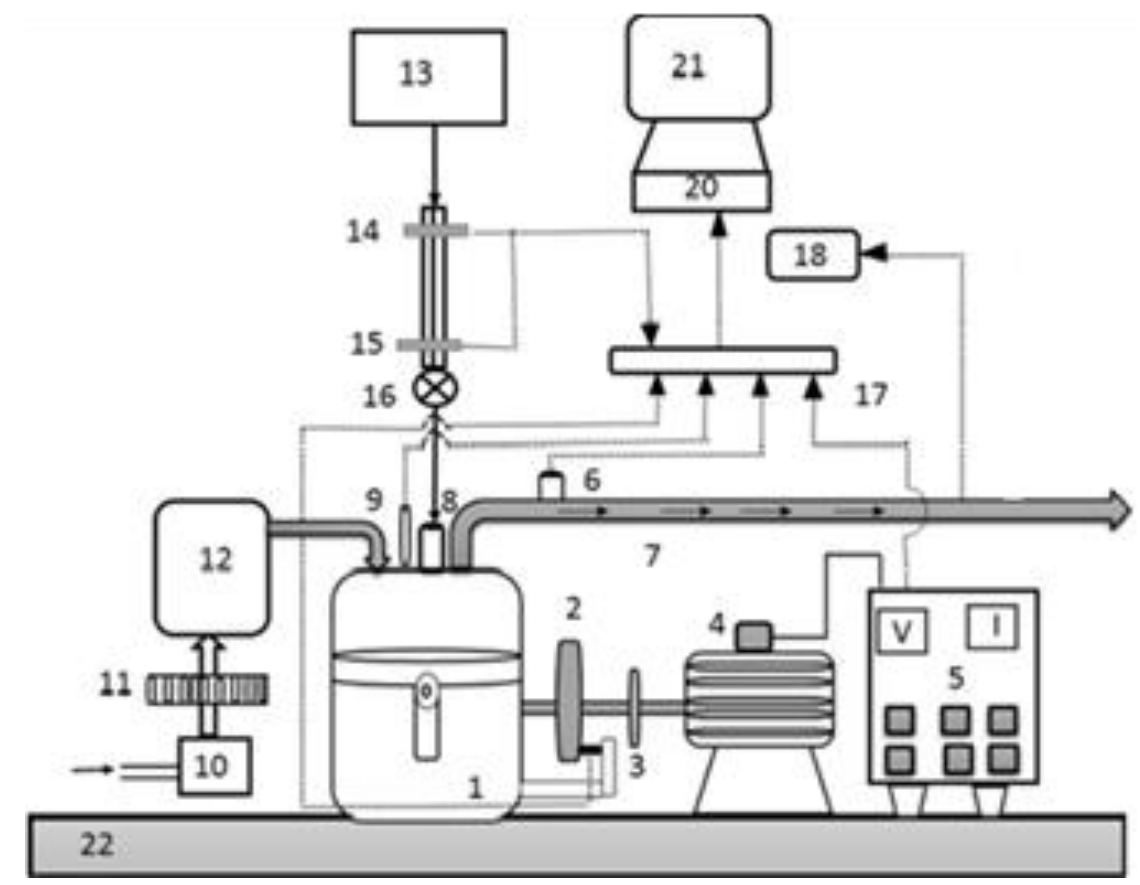

Fig.2 Engine Experimental setup. 1. Engine, 2. Fly wheel, 3. Speed sensor, 4. AC dynamometer, 5. Resistive load cell, 6. EGT sensor, 7. Exhaust manifold, 8. Fuel injector, 9. Pressure transducer, 10. Air filter, 11. Air flow sensor, 12. Air box, 13. Fuel tank, 14. High fuel level optical sensor, 15. Low fuel level optical sensor, 16. Fuel pump, 17. Control panel, 18. Exhaust gas analyser, 20.Data acquisition system, 21. Monitor 22. Engine base.

The exhaust emissions of the engine are analysed using an exhaust gas analyser. The constituents of the exhaust gas measured are $\mathrm{CO}(\%), \mathrm{CO} 2(\%), \mathrm{O} 2(\%), \mathrm{HC},(\mathrm{ppm}), \mathrm{NOx}(\mathrm{ppm})$ and $\mathrm{Ox}(\mathrm{ppm})$. Table I gives the technical specifications of different components used in the test rig.]

Table I Specification of VCR engine test rig

\begin{tabular}{|l|l|}
\hline ENGINE PARAMETERS & \\
\hline Rated Power and Speed & $3.5 \mathrm{~kW} @ 1500 \mathrm{rpm}$ \\
\hline Bore×Stroke & $87.5 \mathrm{~mm} \times 110 \mathrm{~mm}$ \\
\hline Compression ratio & $17.5: 1$ \\
\hline Nozzle operating pressure(bar) & 200 \\
\hline Injection timing (CA) & $25^{\circ} \mathrm{Btdc}$ \\
\hline Intake valve opening/closing & $4.5^{\circ} \mathrm{bTDC} / 35.5^{\circ} \mathrm{Abdc}$ \\
\hline Exhaust value opening/closing & $35.5^{\circ} \mathrm{bBDC} / 4.5^{\circ} \mathrm{Atdc}$ \\
\hline
\end{tabular}

\section{RESULTS AND DISCUSIIONS}

\section{A. Characterisation of Annona Squamosa Seed Cake Bio-Oil}

The pyrolysis reactor was maintained at different temperatures ranging from 450 to $550 \circ \mathrm{C}$ for the determination of optimum temperature at which the maximum bio-oil yield from Mahua seed was obtained. Table II provides the details of pyrolysis products obtained from Mahua seed pyrolysis at different temperatures. It is evident from the table that the maximum bio-oil yield of $40 \%$ was obtained from Annona squamosa seed at $500 \circ \mathrm{C}$. The maximum bio-oil yield at $500 \circ \mathrm{C}$ can be attributed to thermal cracking, depolymerization, and recondensation of secondary reactions. 


\section{International Advanced Research Journal in Science, Engineering and Technology}

Vol. 6, Issue 5, May 2019

Table II Effect of temperature on product yield

\begin{tabular}{|c|c|}
\hline Temperature range & Oil yield \% \\
\hline 450 & 33 \\
\hline 475 & 38 \\
\hline 500 & 40 \\
\hline 525 & 37 \\
\hline 550 & 35 \\
\hline
\end{tabular}

The obtained Annona squamosa seed cake oil is a dark brown organic oil comprising different molecular weight compounds in it. The physical properties such as density, kinematic viscosity, flash point, fire point, pour point and cetane number are determined as per the ASTM standards. These important physical properties of bio-oil in comparison with diesel are listed in table III.

Table III Physical properties of Annona squamosa seed cake bio oil in comparison with Diesel.

\begin{tabular}{|l|c|c|c|}
\hline \multicolumn{1}{|c|}{ Properties } & ASTM method & Diesel & $\begin{array}{c}\text { ANNONA SQUAMOSA } \\
\text { SEED CAKE BIOOIL }\end{array}$ \\
\hline Density @ $40^{\circ} \mathrm{C}\left(\mathrm{kg} / \mathrm{m}^{3}\right)$ & ASTM D 1298 & 833 & 921.3 \\
\hline Kinematic Viscosity @ 40 ${ }^{\circ} \mathrm{C}(\mathrm{cSt})$ & ASTM D 445 & 2.58 & 23.19 \\
\hline Calorific value $(\mathrm{MJ} / \mathrm{kg})$ & ASTM D 4809 & 43.8 & 41.8 \\
\hline Flash Point $\left({ }^{\circ} \mathrm{C}\right)$ & ASTM D 3828 & 50 & 84 \\
\hline Fire point $\left({ }^{\circ} \mathrm{C}\right)$ & ASTM D 92 & 56 & 118 \\
\hline Cetane number & ASTM D 976 & 50 & 37.7 \\
\hline
\end{tabular}

\subsection{Performance parameters:}

\subsubsection{Brake Thermal Efficiency (BTE):}

The variation of brake thermal efficiency with load for diesel and different Annona squamosa seed cake oildiesel blends is shown in fig 3. The BTE increases steadily with engine load for all the tested fuels. The fuel consumption rate gets increased as the load increases. It can be observed that the brake thermal efficiencies are closer to each other except the B10CR16 blend. A maximum of 29\% BTE is found for B20 at full load. It is found that the $27 \%$ increase in brake thermal efficiency for B20 compared to the diesel at full load condition. The rate of fuel consumption is higher for the blends, and it is found the maximum for the B20CR16 blend. The high viscosity and density of blends may cause higher fuel consumption. BTE is the ratio of brake power to the input energy of the fuel which is the product of fuel flow rate and calorific value. The calorific value of the blends decreases with the percentage increase of bio-oil in the blend. Due to the less amount of fuel consumption as the biooil blend ratio increases the BTE of the engine is greater for the biooil blends compared to the diesel.

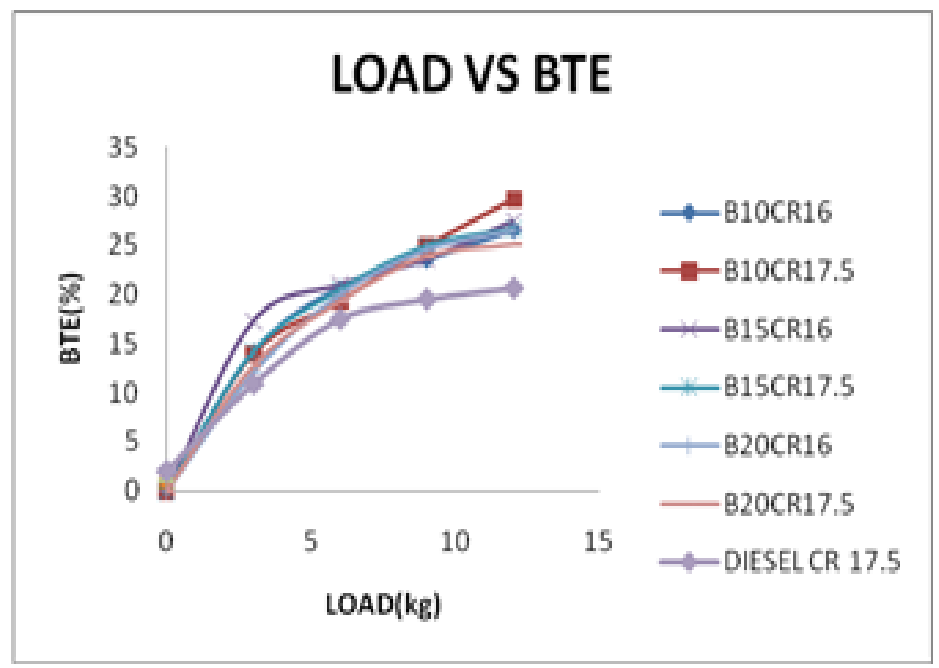

Fig.3 Variation of Brake thermal efficiency for different loads. 


\section{International Advanced Research Journal in Science, Engineering and Technology}

Vol. 6, Issue 5, May 2019

\subsubsection{Brake specific energy consumption (BSEC):}

Fuels with different calorific value and density are not comparable with brake specific fuel consumption (BSFC). Hence, BSEC is used which is the product of BSFC and calorific value. Fig. 4 shows the variation of BSEC with load for various test fuels in this study. The BSEC was found to be $17.52 \mathrm{MJ} / \mathrm{kWh}$ for diesel at full load. For the B10 B15 and $\mathrm{B} 20$ of the compression ratio 17.5 blends is $12.22,13.47$ and $13.87 \mathrm{MJ} / \mathrm{kWh}$ respectively. BSEC decreases with the increase in the load for all the test fuels as expected. The BSEC increases for the Annona squamosa seed cake oil-diesel blends compared to that of diesel for all loads due to the lower calorific value of the blends. At full load condition the B20CR17.5 blend shows the maximum BSEC because of the lower calorific value and the increased amount of fuel injection.

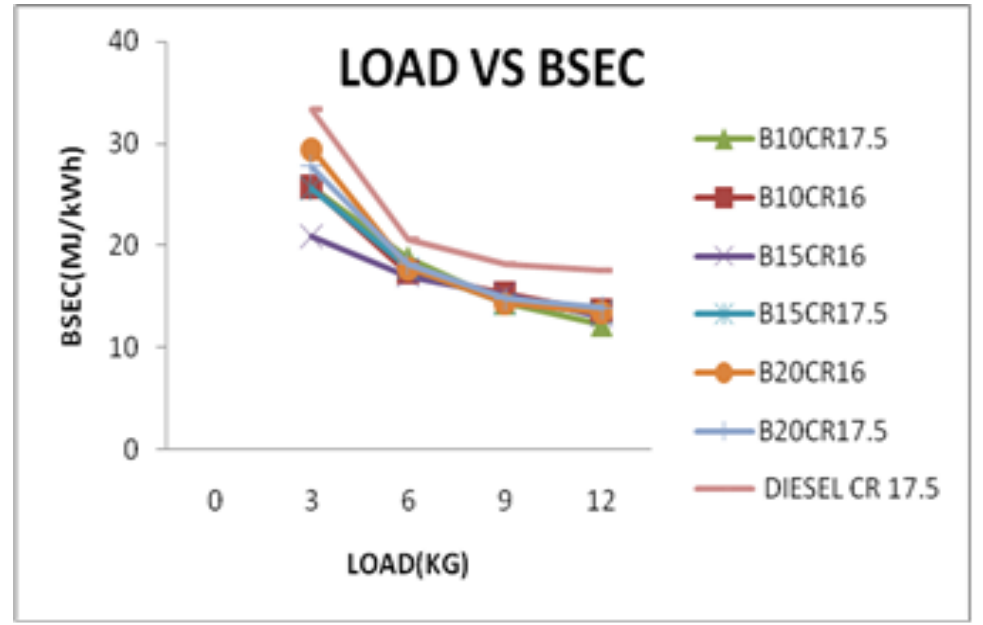

Fig.4 Variation of Brake specific energy consumption for different loads.

\subsection{Combustion Parameters:}

\subsubsection{Cylinder Pressure:}

The variation of cylinder pressure with crank angle at full load for the test fuels is shown in fig 5 .The cylinder pressure of the CI engine depends on upon the mass fraction of fuel burned during the premixed phase or uncontrolled phase of combustion. This is governed mainly by the ignition delay and sprays developed by the injected fuel. The premixed phase combustion can be measured by the accumulated fuel quantity during the ignition delay period. The volatility and viscosity of the fuel play a significant role in the atomization rate and air/fuel mixture formation. It is clear from the figure that the maximum pressure is obtained for the B20 diesel blend. The rate of pressure rise has been increased because of the higher ignition delay. Due to the higher density of the Annona squamosa seed cake oil, the fuel accumulated in the premixed combustion phase is higher than that of diesel. Increase in the cylinder pressure suppresses the dissociation of the combustion products and it will result in the incomplete combustion.

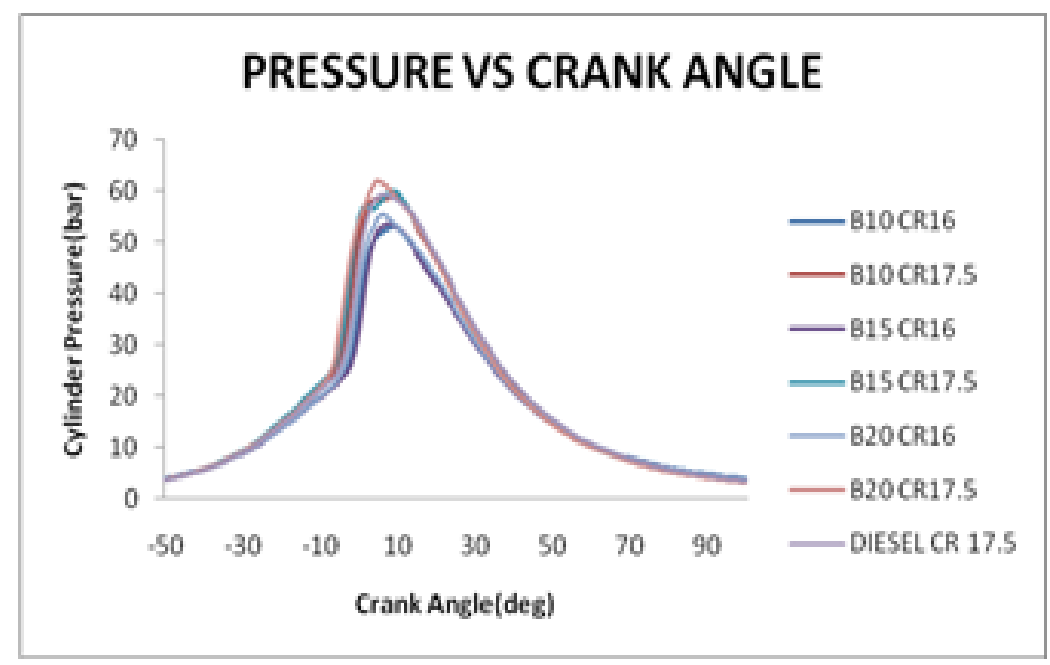

Fig.5 Variation of Cylinder pressure with Crank angle. 


\section{International Advanced Research Journal in Science, Engineering and Technology}

Vol. 6, Issue 5, May 2019

\subsubsection{Heat release rate:}

The amount of heat added to the engine cylinder can be computed by the heat release analysis based on the combustion pressure data. The HRR was obtained by performing the first law of thermodynamic analysis of pressure crank angle data proposed by Heywood [8].

$$
\frac{\mathrm{dQch}}{\mathrm{d} \theta}=\frac{\gamma}{\gamma-1} \mathrm{p} \frac{\mathrm{dV}}{\mathrm{d} \theta}+\frac{1}{\gamma-1} \mathrm{~V} \frac{\mathrm{dp}}{\mathrm{d} \theta}+\frac{\mathrm{dQht}}{\mathrm{d} \theta}
$$

Where $\frac{\mathrm{dQch}}{\mathrm{d} \theta}$ is gross heat release rate $(\mathrm{J} / \mathrm{CA}), \mathrm{V}=$ cylinder volume $(\mathrm{m} 3), \mathrm{P}=$ in-cylinder pressure $($ bar $), \theta=$ crank angle degree, $\frac{\mathrm{d} Q \mathrm{ht}}{\mathrm{d} \theta}=$ rate of heat transfer from the wall $(\mathrm{J} / \mathrm{CA})$.

The cylinder pressure data from 200 consecutive cycles were recorded on a high-speed computer connected to the digital data acquisition system and then averaged. Fig. 6 depicts the variation of the heat release rate with crank angle at full load for diesel and the Annona squamosa seed cake oil-diesel blends. The HRR is slightly negative during the ignition delay period due to the cylinder heat transfer losses and the cooling effect of the fuel vaporization. The HRR is the highest for B15 blend followed by other Annona squamosa seed cake oil blends and the diesel. The HRR of the higher Annona squamosa seed cake oil blend ratio is decreased due to the accumulation of the fuel inside the cylinder which results in the unburned gases. The heat for the unburned gases was not recovered due to the ignition delay. The maximum HRR for diesel, B10, B15 and B20 are by about 55, 59, 62 and 52 J/kg respectively, at full load.

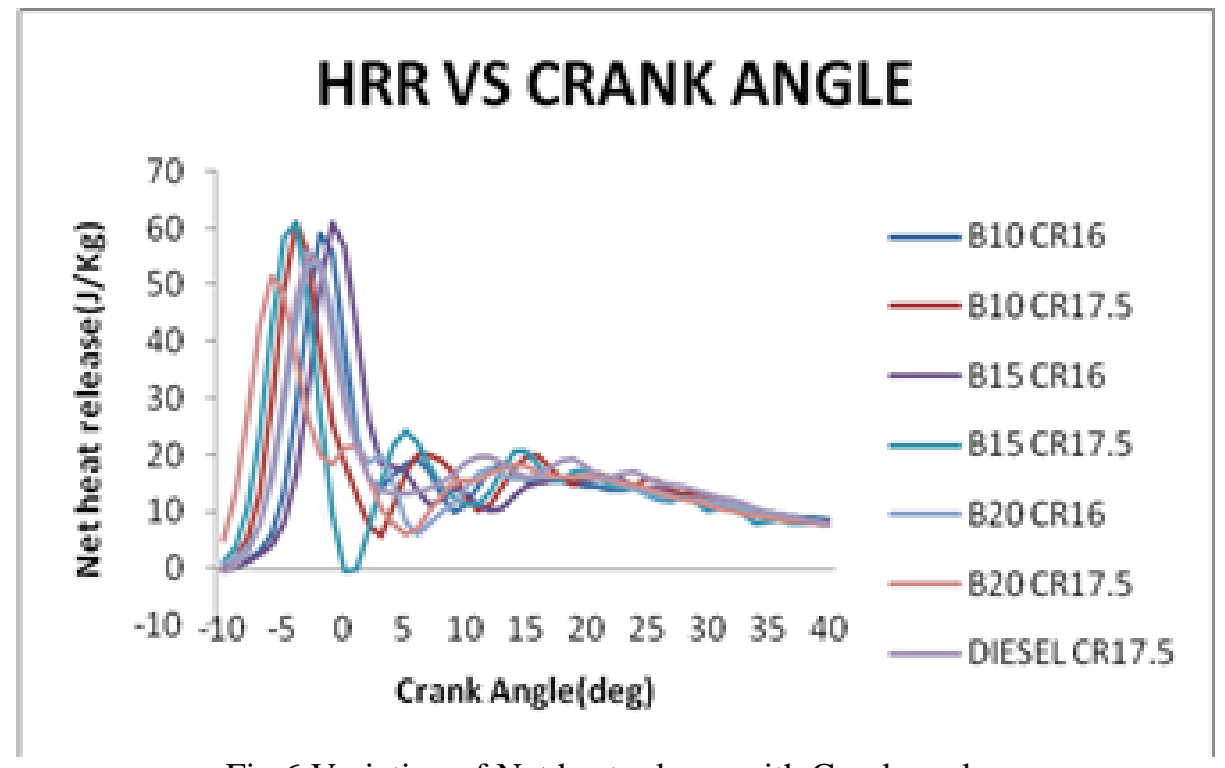

Fig.6 Variation of Net heat release with Crank angle

\subsection{Emission Parameters:}

\subsubsection{Carbon monoxide (CO) emission:}

Fig.7 shows the variation of $\mathrm{CO}$ emission with load for diesel and the Annona squamosa seed cake oil blends. The intermediate product of combustion is $\mathrm{CO}$, formed mainly due to the incomplete oxidation of the fuel during combustion. If the combustion is complete, then $\mathrm{CO}$ is converted to $\mathrm{CO} 2$. In general, the $\mathrm{CO}$ emissions is less in $\mathrm{CI}$ engines than in SI engines, which is due to the lean operation of air/ fuel mixture in CI engines. As the load increases the rate of fuel consumptions gets increased which results in the formation of more amount of CO emission. The fuel air mixture becomes rich as the load increases and it leads to the incomplete combustion of the fuel. The emissions CO is lower in the case of Annona squamosa seed cake oil -diesel blends compared to that of diesel operation at full load, which is due to lower calorific value of fuel which overcomes the incomplete oxidation. The higher viscosity of the MPO-diesel blends might result in long spray penetration, large fuel droplets and poor atomization results in lower CO emissions. The CO emission for diesel, B10, B15 and B20 are 0.33, 0.3, 0.26 and $0.75 \%$ respectively at full load condition. 
Vol. 6, Issue 5, May 2019

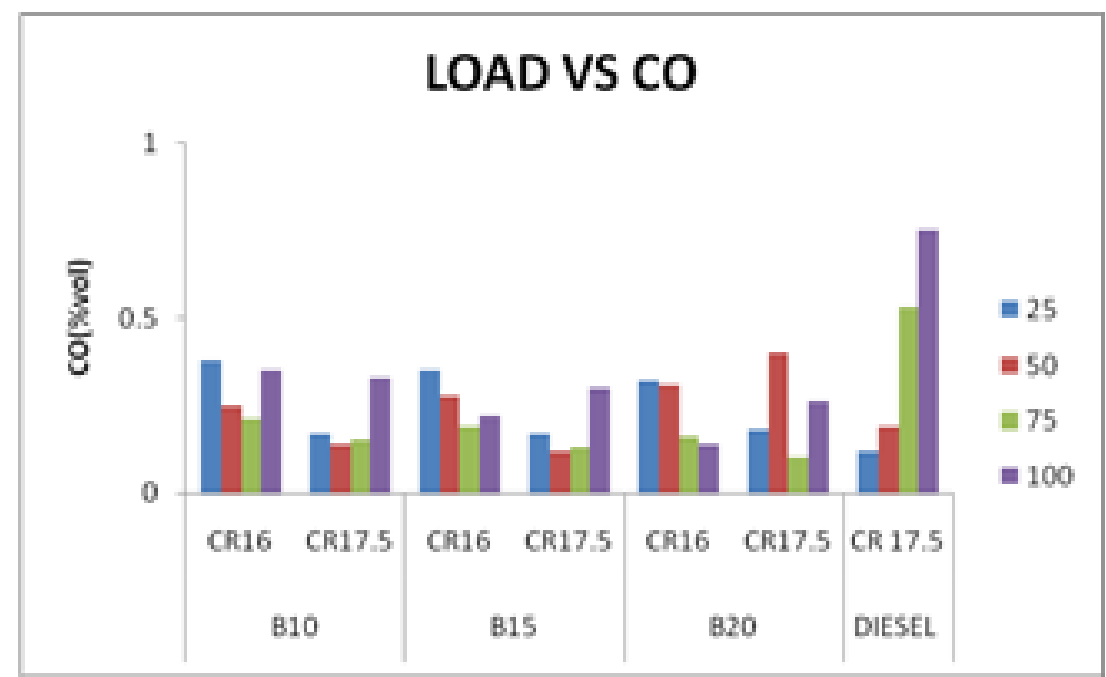

Fig.7 Variation of CO emission with different loads

\subsubsection{Hydrocarbon (HC) emission:}

Incomplete combustion of the fuel results in hydrocarbon (HC) emission. In IC engine, the HC emissions were formed due to poor fuel volatility, improper atomization of the fuel, the high viscosity of the fuel and flame quenching at walls of the combustion chamber. Fig 8 shows the variation of HC emission with load for diesel and the Annona squamosa seed cake oil-diesel blends. In this study, the HC emission increases with the increase in load for all the test fuels. The $\mathrm{HC}$ emission is lower for the Annona squamosa seed cake oil -diesel blends compared to that of diesel for all the engine operation. The increase in the bio-oil percentage results in a lower HC emission which is due to high viscosity and lower heating value caused by poor atomization of the fuel. The HC emissions for diesel, B10, B15and B20 are 524, 201,143 and 78 ppm respectively, at full load. A lower HC emission is noticed for the Annona squamosa seed cake oil-diesel blends than for diesel which may be due to improper spray caused by higher viscosity, the presence of unsaturated hydrocarbons in the Annona squamosa seed cake oil, which are unbreakable during the combustion process.

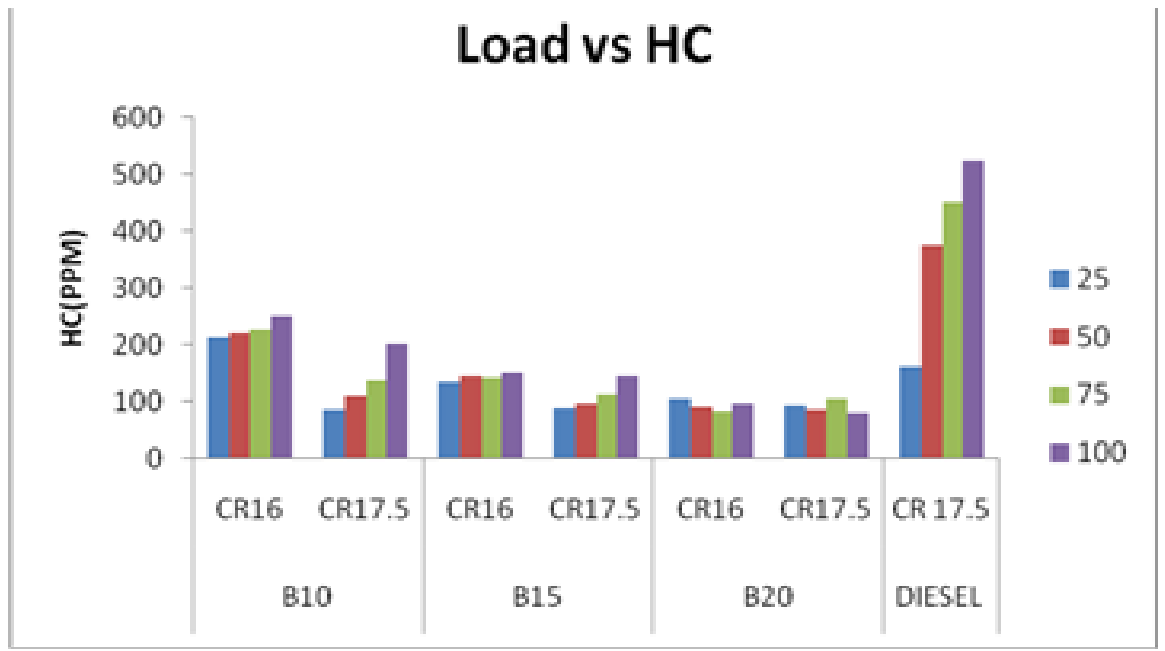

Fig.8 Variation of HC emission with different loads

\subsubsection{Nitric oxide (NO) emission:}

The nitric oxide (NO) emission is a strong function of temperature, pressure and total oxygen concentration in the combustion chamber. The increase in the gas temperature with loads results in higher NO emission for all the tested fuels. The variations of the NO emission with load for diesel and the Annona squamosa seed cake oil -diesel blends are shown in fig 9. The NO emission for diesel, B10, B15 and B20 are 1650, 1437, 1501 and 1185 ppm respectively, at full load. The lower values of the NO emission for the bio-oil blends than that of diesel may be due to the lower HRR.The higher ignition delay causes the hot gases from combustion have a higher exchange surface with the cylinder and thus a lower temperature. As mentioned previously that bio-oil contains high moisture content which may reduce the cylinder gas temperature. 


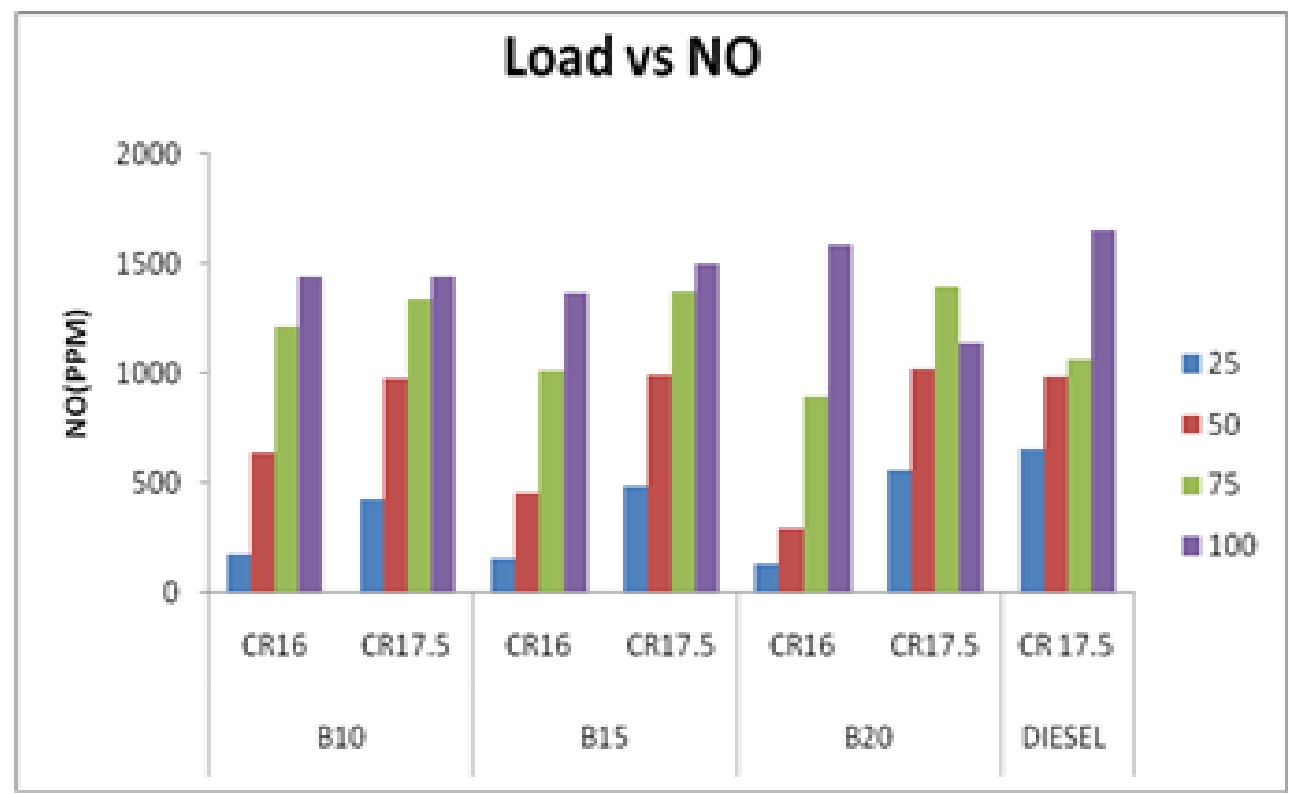

Fig.9 Variation of NO emission with different loads

\section{CONCLUSION}

The combustion, performance, and emission characteristics of a DI diesel engine fueled with the Annona squamosa seed cake biooil-diesel blends were experimentally investigated. The pyrolysis experiments were carried out in between 450 and $500^{\circ} \mathrm{C}$ with a heating rate of $20^{\circ} \mathrm{C} / \mathrm{min}$. The optimum bio-oil yield of $40 \%$ obtained at $500^{\circ} \mathrm{C}$. The high viscous and low cetane Annona squamosa seed cake bio oil is not suitable for direct utilization in a diesel engine, but it can be used only in the blended form by emulsion process with diesel without any engine modification. The combustion of Annona squamosa seed cake bio oil -diesel blends is slower than that of diesel is due to the low cetane number, higher density, and poor volatility. The HC and CO emissions were lower for the Annona squamosa seed cake bio oil -diesel blends than diesel. The lower NO emission was found to be about $28 \%$ for B20, in comparison with diesel at full load due to increased ignition delay. At full load condition, it is found that the $27 \%$ increase in brake thermal efficiency for B20 compared to the diesel. From this experimental investigation, it is recommended that up to $20 \%$ bio-oil blend can be used in the diesel engine for better performance and minimizing the emission to the environment.

\section{REFERENCES}

[1]. Energy Statistics, Government of India 2017 http://www.mospi.nic.in/sites/default/files/publication_reports/Energy_Statistics_2017r.pdf.pdf.

[2]. M. Krishnamoorthi ,R.Malayalamurthi,2017 Experimental investigation on performance, emission behavior and exergy analysis of a variable compression ratio engine fueled with diesel - aegle marmelos oil - diethyl ether, blends,Energy,Vol:128,Pages:312-328.

[3]. Vikranth Vollia and R. K. Singh 2012 Production of bio-oil from mahua de-oiled cake by thermal pyrolysis, Journal of Renewable and Sustainable Energy, Vol:4 Pages:312-325.

[4]. Vikranth Volli ,R. K. Singh,S. Murugan,2016,The Use of Mustard Cake Pyrolytic Oil Blends as Fuel in a Diesel Engine, Waste and Biomass Valorization,Vol:41,Pages:128-137.

[5]. Seokhwanlee,TaeyoungKim,KernyongKang,2016,Performance and emission characteristics of a diesel engine operated with wood pyrolysis oil, Institution of Mechanical Engineers, Vol:115,Pages:228-236.

[6]. S. Murugan,M.CRamaswamy,G.Nagarajan,2015,Assessment of pyrolysis oil as an energy source for diesel engines, Fuel Processing Technology,Vol:90,Pages:67-74.

[7]. DebalaxmiPradhan,Harisankarbendu,R.K.Singh,S.Murugan,2016,Mahua seed pyrolysis oil blends as an alternative fuel for light duty diesel engines,Energy,Vol:118,Pages:600-612.

[8]. Heywood J, Internal Combustion engine fundamentals, McGraw Hill Education, 2011. 